\title{
Fires without tanoak: the effects of a non-native disease on future community flammability
}

\author{
J. Morgan Varner $(1) \cdot$ Howard G. Kuljian · Jesse K. Kreye $(\mathbb{D}$
}

Received: 24 September 2016/Accepted: 19 April 2017/Published online: 27 April 2017

(C) Springer International Publishing Switzerland 2017

\begin{abstract}
Non-native pathogens affect forests throughout North America, resulting in changes in species composition, structure, and ecosystem processes. We studied the effects of the emergent disease sudden oak death (SOD) and the resulting functional extinction of tanoak, a highly susceptible native tree with flammable litter, on future community flammability. We quantified four flammability metrics (flame height; flaming duration; smoldering duration; and fuel consumed) for litter from each of five species that co-occur with tanoak and for species mixtures with and without tanoak $(\mathrm{n}=14)$. We combined these flammability metrics in a Principal Components Analysis to evaluate potential shifts in litter flammability from pre-SOD (with tanoak litter) to post-SOD
\end{abstract}

Howard G. Kuljian: Deceased.

J. M. Varner $(\square)$

Pacific Wildland Fire Sciences Laboratory, USDA Forest

Service, 400 North 34th Street Suite 201, Seattle,

WA 98103, USA

e-mail: jmorganvarner@gmail.com

H. G. Kuljian

Wildland Fire Laboratory, Department of Forestry and Wildland Resources, Humboldt State University, One Harpst Street, Arcata, CA 95521, USA

J. K. Kreye

Department of Forest Resources and Environmental Conservation, 310 West Campus Drive, Virginia Tech, Blacksburg, VA 24061, USA (where tanoak was replaced equally with remaining species). Litter flammability changed following the loss of tanoak, but the differences were species- and community-specific. Mixed-evergreen fuels where coast Douglas-fir litter replaced tanoak experienced consistent declines in flammability. Few substantive changes occurred in communities where coast redwood or other hardwoods co-occurred. We found consistent synergistic flammability effects when multiple species' litters were mixed; in cases where two or more species were mixed, most $(75 \%)$ combinations burned with higher intensity $(+8.1 \%)$ and fuelbeds flamed for a longer duration $(+17.1 \%)$. Our work demonstrates that potential surface fire behavior in northwestern California may be dampened where Douglas-fir replaces tanoak, while those communities with other hardwoods or coast redwood may have redundant fuels and tanoak's absence in future fires may be inconspicuous. These results underscore the potential for cascading effects of non-native pathogens on ecosystem function in fire-prone ecosystems.

Keywords Douglas-fir · Fire regimes · Functional extinction · Litter · Notholithocarpus densiflorus . Phytophthora ramorum . Sudden oak death

\section{Introduction}

The invasion of non-native pathogens has altered a large number of North American forests (Lovett et al. 
2006; Moser et al. 2009; Aukema et al. 2010). The consequences of these diseases include elevated tree stress and mortality, shifts in species composition and structure, and alterations to fundamental ecosystem processes (Rizzo and Garbelotto 2003; Ellison et al. 2005; Lovett et al. 2006). Noted North American examples of non-native pathogen-induced changes include Cryphonectria parasitica $\times$ Castanea dentata (chestnut blight and American chestnut), Phytophthora lateralis $\times$ Chamaecyparis lawsoniana (Port Orford-cedar disease), and Cronartium ribicola $\times$ Pinus sp. (white pine blister rust and pines in the subgenus Strobus) (Paillet 2002; Ellison et al. 2005; Tomback and Achuff 2010; Jules et al. 2014). In contrast to increased attention focused on the disturbance interactions between non-native plants and fire regimes (Brooks et al. 2004; Mandle et al. 2011; Setterfield et al. 2013), research that evaluates the effects of non-native diseases on altering characteristics of future fire regimes in naïve ecosystems is comparatively rare (but see Mola et al. 2014).

An emergent non-native disease causing substantial changes in Pacific West US forests is sudden oak death (SOD), a disease caused by Phytophthora ramorum (Rizzo and Garbelotto 2003). SOD was discovered in California in the mid-1990s and has since spread extensively into forests and woodlands in California and into southwestern Oregon. SOD infects over 40 native tree genera in the western US, and is implicated in the mortality of several members of the Fagaceae family (Rizzo et al. 2005). Of species killed, none are affected more severely than tanoak (Notholithocarpus densiflorus syn. Lithocarpus densiflorus), a native tree species that co-dominates mixed-evergreen and coast redwood forests in California and Oregon (Sawyer 1980; Tappeiner et al. 1990). Tanoak lacks a mechanism to survive SOD and succumbs to the disease in a progression of stages. Each of these stages corresponds with changes in fire regimes: infection results in crown- to canopy-scale dead leaf retention increasing the potential for crown fire ignition (Kuljian and Varner 2010, 2013) and the eventual accumulation of senesced branch and stem fuels elevate surface fire hazard (Valachovic et al. 2011; Forrestel et al. 2015). Recent evidence implicates these changes in fuels to observed increases in post-fire tree mortality and soil damage (Metz et al. 2011, 2013). As with many introduced species, longer-term (decades to century) changes are less clear. With continued spread and mortality caused by SOD, it is reasonable to expect that tanoak will be extirpated and functionally extinct in large areas of its native range within the next few decades (Meentemeyer et al. 2011). Recent studies have begun to explore the potential changes in species composition, structure, and nutrient dynamics as a result of SOD (Waring and O'Hara 2008; Ramage et al. 2011; Metz et al. 2012; Ramage et al. 2012; Cobb and Rizzo 2016), but the functional loss of tanoak's flammable litter inputs and the resulting implications for the region's fire regimes have not been investigated.

In many forests, surface fire behavior is driven primarily by the flammability of senesced litter and surface woody fuels (Anderson 1982; Varner et al. 2015). Plant flammability encompasses the fundamental mechanisms of fire behavior, the combination of the ignition, burning, and extinction characteristics of fuel (Anderson 1970). Flammability has been divided into four descriptors: (1) ignitability, the lag to ignition; (2) intensity, the fuel's energy release rate; (3) sustainability, the duration of flaming; and (4) consumability, the proportion of the fuel combusted (Fonda et al. 1998). Although limited, laboratory-measured flammability tracks patterns in field fire behavior patterns (Engber et al. 2011; Wenk et al. 2011), offering opportunities in laboratory settings to manipulate fuels and isolate mechanisms that drive changes (Mola et al. 2014). Species, and even closely related congeners, often exhibit marked differences in flammability (Engber and Varner 2012). Highly flammable fuels increase fire intensity causing mortality of proximal competitors, opening growing space for offspring, protecting source trees from long duration heating, or otherwise governing ecosystem composition and structure (Kane et al. 2008; Gagnon et al. 2010; Engber and Varner 2012; Mola et al. 2014). Among native hardwoods in the western US, tanoak litter ranks among the most flammable (Engber and Varner 2012), with high intensity and consumability and low sustainability, characteristics similar to noted fire-adapted western conifers (Fonda et al. 1998; Fonda 2001). This observation raises the question: What will be the effect of tanoak extirpation on future flammability, and potentially fire regimes, in western forests and woodlands where tanoak once co-dominated?

The primary objective of this study was to determine how tanoak extirpation, or "functional extinction" (sensu Ellison et al. 2005), may alter the future 
flammability of fire-prone northwestern California forests. We hypothesized that fuelbed flammability would decline across communities with the loss of flammable tanoak litter (and corresponding replacement by other native species), resulting in positive feedbacks that may further diminish community flammability (Kane et al. 2008; Nowacki and Abrams 2008). Additionally, we sought to quantify the flammability of litter from the co-occurring forest species, for which limited data have been available, and of mixtures of co-occurring species. To date, few studies have compared burning of mixed litterbeds (fuelbeds with more than one species; but see Curt et al. 2011; de Magalhães and Schwilk 2012; Van Altena et al. 2012) to the burning characteristics of single species. Collectively, these results will help clarify the effects of non-native pathogens on disturbance processes in "future" or novel ecosystems and contribute to our general understanding of plant community flammability.

\section{Methods}

Litter collection and burning

We collected forest floor litter from mixed-evergreen and coast redwood forests in northwestern California from five dominant tree species. Mixed-evergreen forests (Sawyer 1980) are dominated by mixtures of coast Douglas-fir (Pseudotsuga menziesii var. menziesii), tanoak, California bay (Umbellularia californica), and Pacific madrone (Arbutus menziesii) and are characterized by low and mixed severity fire regimes with historic frequencies between 5 and 20 years (Wills and Stuart 1994; Stuart and Stephens 2006). Coast redwood forests are overwhelmingly dominated by coast redwood (Sequoia sempervirens) with tanoak as a common codominant, particularly in upland or slope forests or those with a history of logging (Noss 2000). Redwood forests historically burned with high frequency (fires every ca. 5-15 years; Stephens and Fry 2005; Stuart and Stephens 2006), and lower severity. From each species, we collected recently cast surface litter (superficial Oi horizon) beneath twelve different trees within single 1 ha stands. Litter beneath tanoak, coast Douglas-fir, California bay, and Pacific madrone was collected from mature mixed-evergreen forests at the L.W. Schatz Demonstration Tree Farm near Maple
Creek, California. Coast redwood litter was collected in the Arcata Community Forest in Arcata, California. Litter was transported to the laboratory, sorted to remove other species and debris, and oven-dried at $60{ }^{\circ} \mathrm{C}$ for $72 \mathrm{~h}$.

Litter samples were combined to represent fuel composition pre-SOD (with tanoak litter as a component) and post-SOD (tanoak litter removed and replaced with other species; Fig. 1). Fuelbeds for each of the five species were constructed using $15 \mathrm{~g}$ (dry weight) of leaf litter. To approximate mixed species fuels, fuelbeds were constructed with equal proportions, by weight, of litter from each potential species. Two-species mixtures consisted of $7.5 \mathrm{~g}$ of each species, three-species mixtures had $5 \mathrm{~g}$ of each species, and four-species mixtures had $3.75 \mathrm{~g}$ of each species. Litter mixtures were agitated in a paper sack to mix the samples, transferred to the burning platform, and ignited within 5 min of removal from drying ovens.

Experimental burning was conducted under laboratory conditions following standard methods (Fonda 2001; Engber and Varner 2012). Litter fuelbeds were constructed within the interior $400 \mathrm{~cm}^{2}$ of a $35 \times 35 \mathrm{~cm}$ lattice of xylene-soaked cotton strings laid on top of a stainless steel platform (Fig. 1). Samples were burned beneath a $2.75 \times 2.75 \mathrm{~m}$ adjustable fume hood. Strings were ignited using a standard lighter from all sides in rapid succession and a timer was started when litter ignited. Maximum flame height (to the nearest $\mathrm{cm}$ ) was visually estimated by two trained observers against a vertical ruler located directly behind the fuelbed (Fig. 1). Flaming duration (s) was measured as the time elapsed between ignition and flame cessation. Smoldering duration (s) was measured from the end of flaming until extinction of glowing. After extinction, all remaining string was removed, the residual ash and unburned leaves weighed, and fuel consumption (\%) was calculated. We burned seven replicates for each of 14 litter mixtures, for a total of 98 burns.

\section{Data analyses}

We compared the flammability of species and species mixtures. For the five individual species, we compared four flammability metrics (flame height, flaming duration, smoldering duration, and fuel consumption) using ANOVA followed by a post hoc Tukey-Kramer HSD when differences were detected $(\alpha=0.05)$. To evaluate the effects of the SOD-caused replacement of 

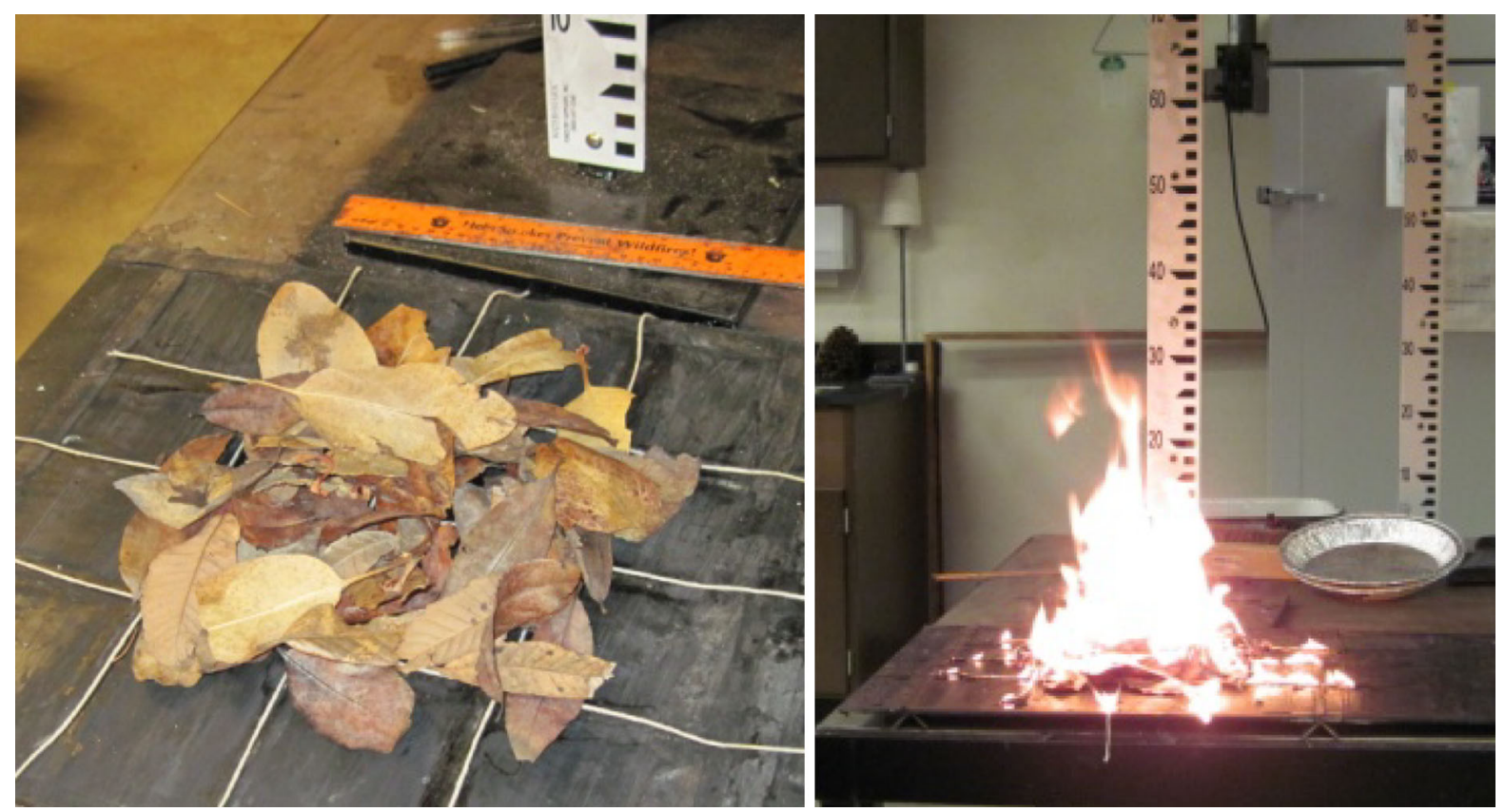

Fig. 1 Laboratory burning of litter from northwestern California forests. Litter samples were spread over a $400 \mathrm{~cm}^{2}$ area on top of a lattice of xylene-soaked cotton string. Samples were

tanoak litter on fuelbed flammability, we analyzed the four flammability metrics using the multivariate Principal Components Analysis (PCA). PCA avoids the issue of multicollinearity inherent in flammability metrics (Varner et al. 2015). Flame height, flame time, mass loss, and smoldering time were combined to create new factor variables and the Bartlett test was used to examine PCA performance. Factors with Eigenvalues $\geq 1.0$ were used for subsequent analysis. Factor scores from each new variable were created for each burn replicate. For each pre- and post-SOD litter combination we compared euclidean distances between pre- and post-SOD litterbeds using the non-parametric perMANOVA. As with PCA, all variables were standardized prior to conducting the perMANOVA.

Non-additive, or synergistic, effects of species mixtures on flammability were also of interest. Synergistic effects occur in multiple species mixtures where the observed flammability exceeds the arithmetic mean of the constituent species' flammability. Dampened effects, in contrast, occur where the observed flammability is lower than the arithmetic mean of the individual species. These deviations were calculated simply as the difference $(\%-$ or +$)$ between observed and expected values for each of the four flammability metrics. ignited and their flame height, flaming duration, smoldering duration, and percent fuel consumed were measured

\section{Results}

Individual species

Litter flammability characteristics differed among the five species when burned separately. Douglas-fir litter was the least flammable, burning with the shortest flames, longest flaming duration, and lowest fuel consumption of the five species compared (Table 1). The three evergreen hardwoods grouped together in most flammability metrics; California bay burned with similar intensity and flaming durations to tanoak and Pacific madrone, but smoldered and consumed less than the other hardwoods. Coast redwood litter flammability overlapped with the three hardwoods for most metrics, and was consistently among the most flammable of all species burned.

\section{Pre-SOD and Post-SOD comparisons}

Litter flammability differed between pre- and postSOD species mixtures, although the responses were dependent on species and community. In the mixedevergreen litters, fuelbed combinations containing Douglas-fir changed in flammability when tanoak was 
Table 1 Burning characteristics $( \pm \mathrm{SE})$ of litter from five dominant tree species in northwestern California mixed-evergreen and coast redwood forests

\begin{tabular}{lllll}
\hline Species & Flame height $(\mathrm{cm})$ & Flaming time $(\mathrm{s})$ & Smoldering time $(\mathrm{s})$ & Mass loss $(\%)$ \\
\hline California bay & $65.4( \pm 3.3) A B$ & $73.0( \pm 5.8) A$ & $146.7( \pm 10.1) B$ & $77.6( \pm 2.0) B$ \\
Coast Douglas-fir & $16.6( \pm 2.1) C$ & $124.0( \pm 13.8) B$ & $321.3( \pm 57.7) A$ & $29.0( \pm 3.8) C$ \\
Coast redwood & $71.4( \pm 3.8) A$ & $59.0( \pm 7.2) A$ & $315.4( \pm 32.5) A$ & $89.7( \pm 0.9) A$ \\
Pacific madrone & $55.9( \pm 1.9) B^{\dagger}$ & $62.0( \pm 4.7) A$ & $305.0( \pm 20.2) A$ & $89.6( \pm 1.0) A$ \\
Tanoak & $58.3( \pm 2.6) B$ & $64.0( \pm 2.9) A$ & $223.0( \pm 11.6) A B$ & $87.0( \pm 1.4) A$ \\
$P$ value & $<0.0001$ & $<0.0001$ & 0.0015 & $<0.0001$ \\
\hline
\end{tabular}

$\dagger$ Pair-wise differences among species (as determined by a post hoc Tukey-Kramer HSD) denoted by different letters in each column

removed (and Douglas-fir increased proportionally; Fig. 2), with diminished flame heights, longer flaming durations, and reduced fuel consumption. Flammability metrics for each species mixture (pre- and postSOD) are listed in Appendix.

Principal Components Analysis (PCA) of community flammability resulted in the combination of burning characteristics into two factor variables (Bartlett test $=201.9, P<0.001)$, accounting for $85 \%$ of the variation in our dataset. Factor 1 consisted of flaming characteristics (flame height and duration) and fuel consumption. Each of these flaming variables were highly correlated with factor 1 (flame height, $\mathrm{r}=0.92$; flame duration, $\mathrm{r}=-0.80$; mass loss, $\mathrm{r}=0.93$ ). Smoldering duration was the primary variable related to factor $2(\mathrm{r}=0.98)$.

The changes in litterbed flammability following the removal of tanoak differed across species mixtures and communities (Fig. 2). Changes were most pronounced in Douglas-fir communities where the relative contribution of Douglas-fir litter increased following removal of tanoak litter. Flaming characteristics (factor 1) differed the most between pre- and post-SOD conditions for Douglas-fir/tanoak $(P<0.001$, Fig. 2$)$, but a difference was also detected for Douglas-fir/Pacific madrone/California bay communities with and without tanoak $(P=0.037)$. A regression between Douglas-fir mass and PCA factor 1 further emphasized the significant and negative effects of this conifer's presence in the fuelbeds $\left(\mathrm{R}^{2}=0.50, P=0.001\right)$. Litter mixtures of communities without Douglas-fir, including redwood communities, were similar in flaming characteristics (factor 1) with or without tanoak (Fig. 2). Changes to smoldering duration (factor 2) following tanoak removal were not significant for any represented community (Fig. 2). High variation in smoldering combustion occurred across litter combinations, with the largest change in smoldering in the Douglas-fir/Pacific madrone/California bay/tanoak, but the change was not significant $(P=0.06)$.

Effects of mixed species on flammability

Mixtures of species' litter resulted in somewhat synergistic effects on litterbed flammability (Fig. 3). Observed flame heights were on average $8.1 \%$ greater in mixed litters in comparison to the average of individual species' values. All but three of the 12 combinations resulted in greater flame heights than would be expected based on arithmetic means of component species. All litter mixtures flamed for a greater duration (17\% longer) than their component species and averaged $17 \%$ longer flame lengths. The majority ( 8 of 12) of litter mixtures smoldered longer than predicted values, with a $17.6 \%$ mean lengthening of the duration. Half of the mixed fuelbeds consumed more than predicted by the averages, and the overall mean was $2.8 \%$ greater mass loss in mixed litters. A few mixtures were contrary to these nonadditive trends (Fig. 3), with no apparent pattern based on species identity or community.

\section{Discussion}

Changes in flammability due to SOD

Our results suggest there will be future changes in community flammability due to functional extinction of tanoak caused by the non-native pathogen causing SOD. These changes reflect altered surface litter flammability, where fires ignite and spread, and were community- and species-specific. The effects of increases in Douglas-fir litter fuels following SOD 


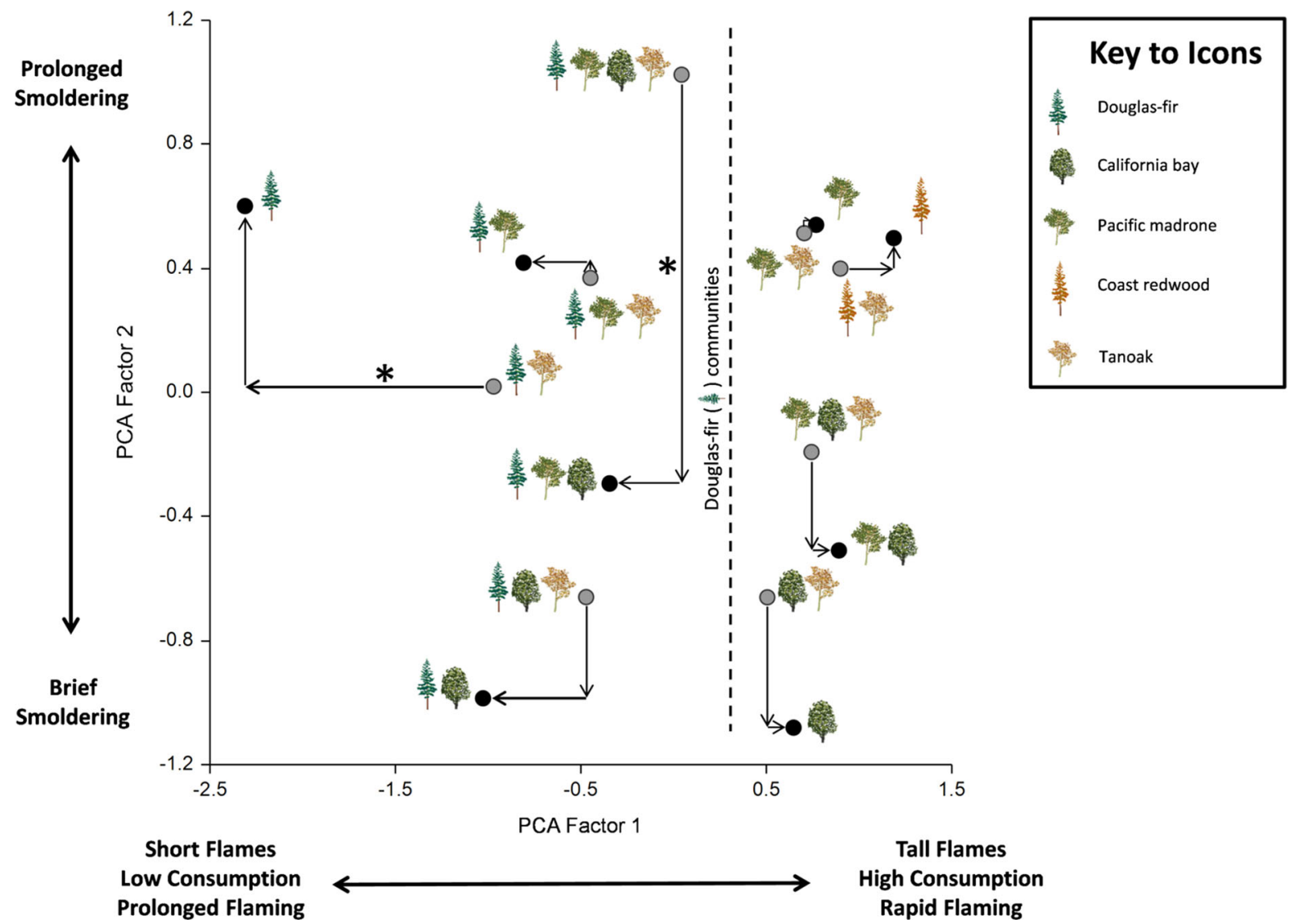

Fig. 2 Results of Principal Components Analysis of flammability pre-sudden oak death (with tanoak) and post- sudden oak death (without tanoak, replaced equitably by remaining species). The vertical line divides the mixed-evergreen forest

are noteworthy; Douglas-fir was burned in isolation using similar methods by Fonda et al. (1998) where they found that Douglas-fir litter was among the least flammable of western USA conifers (10th most flammable of 13 species burned). In wildland fires, Engber et al. (2011) observed that fire temperatures were diminished beneath Douglas-fir in Quercus garryana woodlands, providing field evidence for these lab-scale flammability results. In our regression analysis, flammability declined consistently with additions of Douglas-fir litter. Throughout northwestern California, and to varying degrees across its range, Douglas-fir invades fire-excluded forests, woodlands, and grasslands (e.g. Agee 1993; Engber et al. 2011; Cocking et al. 2012), functionally reducing the local flammability of these fire-prone ecosystems. Invasion by fire-sensitive tree species has been linked to widespread decreases in flammability (so-called litter mixtures that contained Douglas-fir (left half of plot) from those without Douglas-fir (right half of plot). Asterisks denote significant differences between pre- and post-SOD euclidean distances as determined by perMANOVA

"mesophication"; Nowacki and Abrams 2008) of once fire-prone eastern USA forests and more broadly. The mechanisms for mesophication are the deposition of low flammability litter that retains moisture longer and burns with less intensity than the pyrophytic species being replaced (Nowacki and Abrams 2008; Kreye et al. 2013) thereby facilitating the survival of subsequent fire-sensitive invaders. In the case of mixed-evergreen forests, Douglas-fir's projected increase in importance following the SOD-caused functional extinction of tanoak suggests a potential feedback that may reduce future fire intensity and alter the associated ecosystem processes across these landscapes.

California bay has been observed to increase in a variety of post-SOD settings (Brown and Allen-Diaz 2009; Metz et al. 2012) and presents the potential for an additional pathogen-fire regime synergy. California 


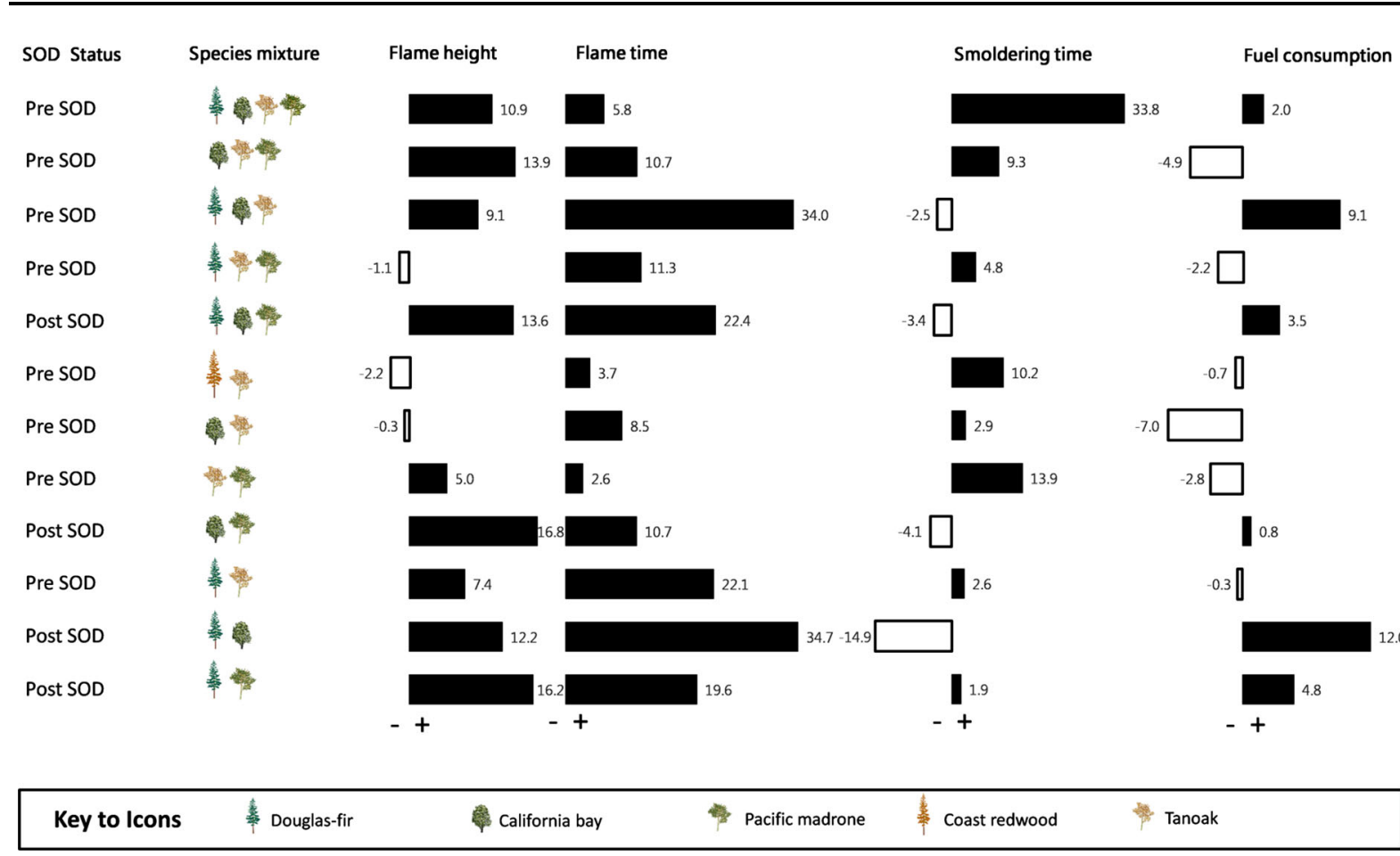

Fig. 3 Comparisons between expected (arithmetic mean of the constituent species) and observed litter flammability in mixed species combinations that include pre- and post-sudden oak

bay foliage serves as the most important source of inoculum for Phytophthora ramorum in tanoak forests (Davidson et al. 2005). While California bay's flammability overlapped other hardwoods (and coast redwood to some degree), its susceptibility to an emergent pathogen currently spreading in the southeastern US (Fraedrich et al. 2008) may complicate future community flammability. California bay is susceptible to Laurel Wilt Disease (Mayfield et al. 2013), an emergent disease caused by Raffaela lauricola (Fraedrich 2008; Fraedrich et al. 2008). Laurel Wilt Disease has yet to reach California, but its effects on member of the Lauraceae in the southeastern US (e.g. Persea, Sassafras, Lindera spp.) suggest similarities to SOD: short-term dead leaf marcescence followed by leaf and branch litterfall, then accumulation of branch and stem woody fuels (Shields et al. 2011). In other sites across the range of SOD affected communities, California bay does not appreciably increase, while coast redwood does (Ramage et al. 2011). In sites where Douglas-fir benefits from the extirpation of tanoak (and perhaps California bay if Laurel Wilt Disease invades the region), reduced community flammability will eventually result. Where death (SOD). Differences were calculated as the percent change (+, synergistic; - , dampening) from expected values to those observed during the experiments

Pacific madrone and/or coast redwood replaces the extirpated hardwoods, community flammability may not change appreciably. These diverse potential scenarios highlight our need to better understand the often complex interactions between and among disturbances (Turner 2010; Metz et al. 2013; Weed et al. 2013).

Synergy in mixed species fuels

The species combinations or "mixed litters" consistently resulted in non-additive effects for our metrics of flammability. While not universal (Van Altena et al. 2012), provocative non-additive or synergistic flammability effects have been found in other western US forest litter combinations (de Magalhães and Schwilk 2012). In Sierran mixed-conifer litters, de Magalhães and Schwilk (2012) found that the most flammable species had a disproportionate effect on mixed litters. The mechanism for non-additive effects may follow de Magalhães and Schwilk's (2012) hypothesis, or the structure that results from contrasting fuel shapes may allow oxygen to reach more surfaces than similarly shaped fuel particles, or perhaps another unknown chemical or physical 
synergy (Van Altena et al. 2012). Future efforts that isolate the proximate mechanisms should also seek to link these laboratory-derived differences to field-scale fires (as in Schwilk and Caprio 2011). In closedcanopy forests (like those we collected in and attempted to mimic here), differences between laboratory results and expectations in the field are likely to be minor, however, in ecosystems with a discontinuous canopy such as woodlands and savannas, the synergistic effects of herbaceous fuels may exceed the simple tree litter mixtures studied to date.

Interestingly, mixed litter flammability results contradict patterns found in the majority of single species flammability research. In the vast majority of cases, fuelbeds that burn with greater intensity (measured here by flame height) burn for a shorter period (rapid release of energy). In contrast, the percentage changes in mixed litter flame height were positively (although weakly) related to flaming duration $(r=0.40)$. The same contrast was found with fuel consumption; a characteristic of past flammability research (Fonda et al. 1998; Engber and Varner 2012; Varner et al. 2015) is that fuels that burn with high intensity also consume the majority of their fuel. Percentage changes in flame height were only weakly related to changes in fuel consumption $(r=0.46)$. The strongest relationship between flammability metric changes was found in flaming duration and mass loss, again the sign $(+)$ contrasting with the vast majority of past single-species research. The mechanisms for these bucked trends in mixed species flammability are unknown ( $c f$. de Magalhães and Schwilk 2012; Van Altena et al. 2012; Varner et al. 2015), but are clear targets for future research, particularly in fire-prone woodlands and forests composed of a high diversity of litter-producing species.

Community-specific change and similarity

While the changes in litter flammability that occurred with the loss of tanoak are noteworthy, we also observed functional redundancy of flammability among the species burned. Pacific madrone closely tracked the flammability of tanoak/Pacific madrone mixtures (Fig. 2). The same phenomenon, with regard to flaming characteristics, was apparent for California bay/Pacific madrone and tanoak mixtures. Where communities have species with redundancy in flammability or fire responses, the loss of one species may have subtle effects on community flammability, diminishing the consequences of the loss on this aspect of ecosystem function.

The lack of change in coast redwood forest flammability following functional extinction of tanoak was somewhat expected. Coast redwood litter is highly flammable (Fonda et al. 1998, Table 1), exceeding tanoak. All of the hardwood species examined here co-occur with coast redwood to some degree, although none as common as tanoak (Tappeiner et al. 1990). The degree to which these hardwoods replace tanoak in redwood ecosystems may determine the degree to which future flammability is altered.

Altered flammability and future fire regimes in former tanoak ecosystems

The implications of altered flammability for changes in future fire regime changes are complicated in space and time. In the near-term, forests with tanoak will continue to suffer mortality and the phased changes in crown and surface fuels and corresponding changes in fire behavior and effects (Kuljian and Varner 2010; Metz et al. 2013; Forrestel et al. 2015). This phenomenon that results from standing dead and then fallen dead fuels will occur across both mixedevergreen and coast redwood forests of the region (Meentemeyer et al. 2011; Metz et al. 2011). The severity of the effects will depend on the timing of fire (time elapsed since tree death, Metz et al. 2013) and the relative density and spatial pattern of killed tanoaks. In forests where tanoak was more dominant (particularly those with past logging), these changes in fire behavior and effects may be exacerbated in the short-term.

In the mid-term, these ecosystems have a mixture of fuels that suggest altered fire behavior and effects. With the additions of downed branches and stems resulting from tanoak mortality, fires will result in local areas of higher intensity (Forrestel et al. 2015) and severity (Metz et al. 2013) within the matrix of low severity fires typical of these ecosystems. Where tanoaks are slow to be killed, local tree torching may occur. As trees fill the new growing spaces generated by tanoak mortality and local high severity fires, Douglas-fir will likely continue its increase (Waring and O'Hara 2008). Where fires interact with these mid-term recovering forests, small Douglas-fir sapling and pole crowns will likely ignite and exacerbate local fire severity (Forrestel et al. 2015). 
Over the long-term, in forests where tanoak is replaced by the remnant unaffected species, the effects on fire regimes will be community- and speciesspecific. In coast redwood ecosystems and in hardwood-dominated communities, our results suggest there may be no appreciable changes in either the flammability or community response to wildland fire. In communities where tanoak is replaced by the less flammable Douglas-fir, however, the effects of functional extinction may be quite important. The shortterm effects of sudden oak death on crown fire ignition, elevated fire severity, subsequent decadalscale increases in woody fuels, and eventual reductions future community flammability may render these ecosystems without contemporary analogs. In other ecosystems invaded by non-native species, drastic shifts in fire regimes have occurred already (e.g. Brooks et al. 2004; Setterfield et al. 2013). At present, we have a poor understanding of whether past introductions of non-native diseases have caused similar effects (Castello et al. 1995; Mola et al. 2014). The relative consequences of losing species that serve foundational, keystone, or umbrella roles are not clear. Regional warming and drying caused by global climate change and concomitant increases in fire frequency in the region (Cayan et al. 2008; Westerling et al. 2006) may further complicate these interactions. As non-native diseases continue their spread in naïve fire-prone ecosystems, we should seek to better understand the novel disturbance regimes that follow.

Acknowledgements Laboratory assistance was provided by C. Shoemaker, M. Jones, and J. Szecsei. Discussions with D. Rizzo and R. Cobb stimulated the development of this research. We benefitted from advice and discussions with E. Engber, T. Shearman, M. Metz, J. Crotteau, and M. DeSiervo. E. Jules provided a thoughtful review of a previous version of the manuscript. The manuscript benefitted from helpful comments provided by the reviewers. Funding was provided by a University of California- California State University Collaborative Research Grant, the L.W. Schatz Demonstration Tree Farm, and the USDA Forest Service Pacific Southwest Region. JMV and HGK conceived and designed the study. HGK and JMV performed the research. JMV and JKK analyzed the data. JMV and JKK wrote the paper.

\section{Appendix}

See Table 2 .

Table 2 Burning characteristics of litterbeds for each pair-wise species combination of pre-Sudden Oak Death and post-Sudden Oak Death (without tanoak)

\begin{tabular}{|c|c|c|c|c|}
\hline Litter mixture height $(\mathrm{cm})$ & Flame time (s) & Flaming time (s) & Smoldering loss $(\%)$ & Mass \\
\hline PSME/NODE & $40.4( \pm 1.7)$ & $120.7( \pm 10.2)$ & $279.1( \pm 37.1)$ & $67.2( \pm 3.0)$ \\
\hline PSME & $16.6( \pm 2.1)$ & $124.0( \pm 13.8)$ & $321.3( \pm 57.7)$ & $29.0( \pm 3.8)$ \\
\hline PSME/ARME/NODE & $41.7( \pm 2.8)$ & $94.0( \pm 2.3)$ & $297.3( \pm 33.1)$ & $67.2( \pm 1.7)$ \\
\hline PSME/ARME & $40.7( \pm 2.8)$ & $115.7( \pm 4.4)$ & $319.1( \pm 28.2)$ & $62.5( \pm 3.7)$ \\
\hline PSME/ARME/UMCA/NODE & $53.9( \pm 3.3)$ & $85.7( \pm 8.3)$ & $376.3( \pm 69.1)$ & $72.4( \pm 1.3)$ \\
\hline PSME/ARME/UMCA & $51.6( \pm 2.0)$ & $111.3( \pm 11.1)$ & $249.0( \pm 14.4)$ & $67.9( \pm 1.5)$ \\
\hline PSME/UMCA/NODE & $51.4( \pm 2.4)$ & $131.9( \pm 12.6)$ & $224.6( \pm 27.0)$ & $71.0( \pm 2.3)$ \\
\hline PSME/UMCA & $46.7( \pm 4.8)$ & $150.9( \pm 4.7)$ & $199.1( \pm 33.7)$ & $60.6( \pm 3.0)$ \\
\hline ARME/UMCA/NODE & $67.9( \pm 2.8)$ & $74.3( \pm 5.1)$ & $248.1( \pm 19.0)$ & $80.7( \pm 1.5)$ \\
\hline ARME/UMCA & $70.3( \pm 3.7)$ & $75.6( \pm 8.5)$ & $216.7( \pm 19.3)$ & $84.5( \pm 0.7)$ \\
\hline ARME/NODE & $57.9( \pm 2.6)$ & $64.7( \pm 2.2)$ & $306.7( \pm 19.7)$ & $86.0( \pm 2.0)$ \\
\hline ARME & $55.9( \pm 1.9)$ & $62.0( \pm 4.7)$ & $305.0( \pm 20.2)$ & $89.6( \pm 1.0)$ \\
\hline UMCA/NODE & $61.7( \pm 3.8)$ & $74.9( \pm 5.1)$ & $190.4( \pm 23.3)$ & $76.9( \pm 2.5)$ \\
\hline UMCA & $65.4( \pm 3.3)$ & $73.0( \pm 5.8)$ & $146.7( \pm 10.1)$ & $77.6( \pm 2.0)$ \\
\hline SESE/NODE & $63.4( \pm 2.7)$ & $63.9( \pm 3.4)$ & $299.6( \pm 42.3)$ & $87.9( \pm 0.7)$ \\
\hline SESE & $71.4( \pm 3.8)$ & $59.0( \pm 7.2)$ & $315.4( \pm 32.5)$ & $89.7( \pm 0.9)$ \\
\hline NODE & $58.3( \pm 2.6)$ & $64.0( \pm 2.9)$ & $223.0( \pm 11.6)$ & $87.0( \pm 1.4)$ \\
\hline
\end{tabular}

Values in parentheses are standard errors 


\section{References}

Agee JK (1993) Fire ecology of Pacific Northwest forests. Island Press, Washington

Anderson HE (1970) Forest fuel ignitability. Fire Technol 6:312-319

Anderson HE (1982) Aids to determining fuel models for estimating fire behavior. USDA Forest Serv. General Technical Report INT-122

Aukema JE et al (2010) Historical accumulation of nonindigenous forest pests in the continental United States. Bioscience 60:886-897

Brooks ML et al (2004) Effects of invasive alien plants on fire regimes. Bioscience 54:677-688

Brown LB, Allen-Diaz B (2009) Forest stand dynamics and sudden oak death: mortality in mixed-evergreen forests dominated by coast live oak. Forest Ecol Manag 257:1271-1280

Castello JD et al (1995) Pathogens, patterns, and processes in forest ecosystems. Bioscience 45:16-24

Cayan DR et al (2008) Climate change scenarios for the California region. Clim Change 87:21-42

Cobb RC, Rizzo DM (2016) Litter chemistry, community shift, and non-additive effects drive litter decomposition changes following invasion by a generalist pathogen. Ecosystems 19:1478-1490

Cocking MI et al (2012) California black oak responses to fire severity and native conifer encroachment in the Klamath Mountains. For Ecol Manag 270:25-34

Curt $\mathrm{T}$ et al (2011) Litter flammability in oak woodlands and shrublands of southeastern France. For Ecol Manag 261:2214-2222

Davidson JM et al (2005) Transmission of Phytophthora ramorum in mixed-evergreen forest in California. Phytopathology 95:587-596

de Magalhães RM, Schwilk DW (2012) Leaf traits and litter flammability: evidence for non-additive mixture effects in a temperate forest. J Ecol 100:1153-1163

Ellison AM et al (2005) Loss of foundation species: consequences for the structure and dynamics of forested ecosystems. Front Ecol Environ 3:479-486

Engber EA, Varner JM (2012) Patterns of flammability of the California oaks: the role of leaf traits. Can J For Res 42:1965-1975

Engber EA et al (2011) The effects of conifer encroachment and overstory structure on fuels and fire in an oak woodland landscape. Fire Ecol 7:32-50

Fonda RW (2001) Burning characteristics of needles from eight pine species. For Sci 47:390-396

Fonda RW et al (1998) Burning characteristics of western conifer needles. Northwest Sci 72:1-9

Forrestel $\mathrm{AB}$ et al (2015) Disease, fuels and potential fire behavior: impacts of sudden oak death in two coastal California forest types. For Ecol Manag 348:23-30

Fraedrich SW (2008) California laurel is susceptible to laurel wilt caused by Raffaelea lauricola. Plant Dis 92:1469

Fraedrich SW et al (2008) A fungal symbiont of the redbay ambrosia beetle causes a lethal wilt in redbay and other Lauraceae in the southeastern United States. Plant Dis 92:215-224
Gagnon PR et al (2010) Does pyrogenicity protect burning plants? Ecology 91:3481-3486

Jules ES et al (2014) Host heterogeneity influences the impact of a non-native disease invasion on populations of a foundation tree species. Ecosphere 5:art105

Kane JM et al (2008) The burning characteristics of southeastern oaks: discriminating fire facilitators from fire impeders. For Ecol Manag 256:2039-2045

Kreye JK et al (2013) Toward a mechanism for eastern North American forest mesophication: the role of litter drying. Ecol Appl 23:1976-1986

Kuljian H, Varner JM (2010) The effects of sudden oak death on crown fire potential in California's tanoak forests. For Ecol Manag 259:2103-2110

Kuljian H, Varner JM (2013) Foliar consumption across a sudden oak death chronosequence in laboratory fires. Fire Ecol 9:33-44

Lovett GM et al (2006) Forest ecosystem responses to exotic pests and pathogens in eastern North America. Bioscience 56:395-405

Mandle L et al (2011) Woody exotic plant invasions and fire: reciprocal impacts and consequences for native ecosystems. Biol Invasions 13:1815-1827

Mayfield AE et al (2013) Suitability of California bay laurel and other species as hosts for the non-native redbay ambrosia beetle and granulate ambrosia beetle. Agric For Entomol 15:227-235

Meentemeyer RK et al (2011) Epidemiological modeling of invasion in heterogeneous landscapes: spread of sudden oak death in California (1990-2030). Ecosphere 2:art7

Metz MR et al (2011) Interacting disturbances: wildfire severity affected by stage of forest disease invasion. Ecol Appl 21:313-320

Metz MR et al (2012) An emergent disease causes directional changes in forest species composition in coastal California. Ecosphere 3:art86

Metz MR et al (2013) Unexpected redwood mortality from synergies between wildfire and an emerging infectious disease. Ecology 94:2152-2159

Mola JM et al (2014) Altered community flammability in Florida's Apalachicola ravines and implications for the persistence of the endangered conifer Torreya taxifolia. PLoS ONE 9:e103933

Moser WK et al (2009) Impacts of nonnative invasive species of US forests and recommendations for policy and management. J For 107:320-327

Noss RF (2000) The redwood forest: history, ecology, and conservation of the coast redwoods. Island Press, Washington

Nowacki GJ, Abrams MD (2008) The demise of fire and "mesophication" of forests in the eastern United States. Bioscience 58:123-138

Paillet FL (2002) Chestnut: history and ecology of a transformed species. J Biogeogr 29:1517-1530

Ramage BS et al (2011) Forest transformation resulting from an exotic pathogen: regeneration and tanoak mortality in coast redwood stands affected by sudden oak death. Can J For Res 41:763-772

Ramage BS et al (2012) Sudden oak death disease progression across two forest types and spatial scales. J Veg Sci 23:151-163 
Rizzo D, Garbelotto M (2003) Sudden oak death: endangering California and Oregon forest ecosystems. Front Ecol Environ 1:197-204

Rizzo DM et al (2005) Phytophthora ramorum: integrative research and management of an emerging pathogen in California and Oregon forests. Annu Rev Phytopathol 43:309-335

Sawyer JO (1980) Douglas-fir-Tanoak-Pacific Madrone (234). In: Eyre FH (ed) Forest cover types of the United States and Canada. Society of American Foresters, Maryland, pp 111-112

Schwilk DW, Caprio AC (2011) Scaling from leaf traits to fire behaviour: community composition predicts fire severity in a temperate forest. J Ecol 99:970-980

Setterfield SA et al (2013) Adding fuel to the fire: the impacts of non-native grass invasion on fire management at a regional scale. PLoS ONE 8:e59144

Shields J et al (2011) Short-term impacts of Laurel Wilt on redbay (Persea borbonia [L.] Spreng.) in a mixed evergreen-deciduous forest in northern Florida. $\mathrm{J}$ For 109:82-88

Stephens SL, Fry DL (2005) Fire history in coast redwood stands in the northeastern Santa Cruz Mountains, California. Fire Ecol 1:2-19

Stuart JD, Stephens SL (2006) North Coast California Bioregion. In: Sugihara NG, van Wagtendonk J, Shaffer KE, Fites-Kaufman J and Thode AE (eds), Fire in California's Ecosystems. University of California Press, pp 147-169

Tappeiner JC et al. (1990) Lithocarpus densiflorus (Hook. \& Arn.) Rehd. tanoak. In: Burns RM and Honkala B (eds),
Silvics of North America, Volume 2, hardwoods. USDA Agriculture Handbook 654, pp 417-425

Tomback DF, Achuff P (2010) Blister rust and western forest biodiversity: ecology, values and outlook for white pines. For Pathol 40:186-225

Turner MG (2010) Disturbance and landscape dynamics in a changing world. Ecology 91:2833-2849

Valachovic YS et al (2011) Sudden oak death-caused changes to surface fuel loading and potential fire behavior in Douglasfir-tanoak forests. For Ecol Manag 261:1973-1986

Van Altena C et al (2012) Species composition and fire: nonadditive mixture effects on ground fuel flammability. Front Plant Sci 3:63

Varner JM et al (2015) The flammability of litter: a synthesis. Curr For Rep 1:91-99

Waring KM, O'Hara KL (2008) Redwood/tanoak stand development and response to tanoak mortality caused by Phytophthora ramorum. For Ecol Manag 255:2650-2658

Weed AS et al (2013) Consequences of climate change for biotic disturbances in North American forests. Ecol Monogr 83:441-470

Wenk ES et al (2011) Within-stand variation in understorey vegetation affects fire behaviour in longleaf pine xeric sandhills. Int J Wildl Fire 20:866-875

Westerling AL et al (2006) Warming and earlier spring increase western US forest wildfire activity. Science 313:940-943

Wills RD, Stuart JD (1994) Fire history and stand development of a Douglas-fir/hardwood forest in northern California. Northwest Sci. 68:205-212 